\title{
IMPACT OF AGRICULTURAL PROTECTION ON AGRICULTURAL GROWTH IN NIGERIA: POLITICAL ECONOMY PERSPECTIVE (1980-2016)
}

\author{
Ejiofor Emmanuel OMEJE * (D), Chukwuemeka John ARENE (D), \\ Chiedozie Benjamin OKPUKPARA (D)
}

\author{
Address: \\ University of Nigeria Nsukka, Faculty of Agriculture, Department of Agricultural Economics, Nsukka, Enugu State, \\ Nigeria. \\ Corresponding author's e-mail: ejiofor.omeje@unn.edu.ng
}

\begin{abstract}
This study examined the impact of agricultural protection and other macroeconomic variables on agricultural growth in Nigeria from 1980 to 2016. The specific objectives were to (i) estimate the level of agricultural protection in Nigeria; (ii) determine the effects of agricultural protection on agricultural growth, and (iii) analyse the causal relationship between agricultural protection and agricultural growth in Nigeria. The data were obtained from annual time series dataset from Central Bank of Nigeria (CBN), World Bank, and Food and Agriculture Organis ation (FAO) and were tested using unit root and cointegration tests. Descriptive statistics, Nominal Protection Coefficient (NPC) model, multiple regression and Granger causality were analytical test used, while the hypotheses were tested with F-test. Results revealed a significant presence of protection in the agricultural sector but not statistically commensurate with the share of agriculture to Nigeria's gross domestic product, (GDP). All hypotheses were tested at $1 \%$ probability level, i.e. $\mathrm{p}<$ 0.01. There was a negative significant relationship between agricultural growth and protection in agriculture. A significant and positive relationship exists between agricultural growth and budgetary appropriation to the agricultural sector, while foreign direct investment and farmers' economic welfare had a non-significant and negative relationship with protection level. There was significant causality running from budgetary appropriation (agriculture) to agricultural protection and from protection level to GDP (agriculture). One of the major recommendations is that government should review its policy instruments, programmes, and projects to ensure that targeted policy objectives such as increase in agricultural growth is achieved by increasing its budget and liberalizing the sector.
\end{abstract}

Keywords: Agricultural protection, agricultural growth, agricultural bud get, political economy, Nigeria JEL: C32, F21, O11, Q14

\section{INTRODUCTION}

Nigeria is one of the developing economies with significant expenditures on agricultural protection through interest and exchange rates differentials, price mechanisms, input subsidies, researches, embargos and regulations promulgated in various protectionistic policy reforms, projects and programmes. Before 1980, African economies were deeply confronted with a crisis situation but Nigeria's experience of the economic crisis was delayed until the early - and mid- the 1980s with the collapse of global oil price. Sequel to this, many African countries including Nigeria adopted remedial and protectionistic measures to address their economic problems, either on their own or at the instance of multinational finance/development agencies such as the International Monetary Fund and the World Bank. Such protectionistic measures, policies, reforms, projects, and programmes executed in Nigeria from 1980 include but not limited to Green Revolution in 1980, Directorate of Food, Roads and Rural Infrastructure (DFRRI) in I986, Better Life for Rural Women in 1992, National
Agricultural Land Development Authority (NALDA,) in 1992, Family Support programme (FSP) and Family Economic Advancement Programme (FEAP) in 1996, National Fadama Development Project (NFDP) in 1990, National Economic Empowerment and Development Strategy (NEEDS) in 1999, National Special Programme on Food Security (NSPFS) in 2002, Root and Tuber Expansion Programme (RTEP) in 2003 (Iwuchukwu and Igbokwe, 2012). Others include the Growth Enhancement Scheme (GES) in 2011 and Agricultural Transformation Agenda (ATA) in 2015 and Agricultural Promotion Policy (APP) in 2016. Each of these reforms consists of one or more of agricultural protection instruments such as tax exemption, tariff reduction, subsidies, credit facilities, reduced interest rate, and regulations and each of them have cost implications.

Agricultural protection is a political economy tool designed to boost domestic production and it is justified not only on the grounds that it can contribute to domestic food security and foster more stable societies, but also because there are sound economic reasons to do so (FAO, 1999). One of these sound economic reasons is to increase 
GDP in the sector but Gardner (1992) allegedly confounded the paradox of growing protection and the declining share of agriculture in his research. Also, worthy to note is that the oil sector which used to contribute a meagre $2.6 \%$ of the GDP in 1960, later contributed $57.6 \%$ to the GDP in 1970 and up to $99.7 \%$ in 1972 (Keke, 1992). Agriculture, on the other hand, contributed only $12 \%$ to the GDP in 1970 and has remained stagnated till 2017. This supposedly has culminated in rising food import bill leading to the persistent huge deficit in the balance of payments over the years (Ugwu, 2007, CBN, 2017). These conflicting claims beg for empirical research and investigation into this paradox of increasing expenditure on protectionistic programmes and decreasing GDP in agriculture.

On the issues of political economy variables that affect protection, Moon, Pino, and Asirvatham (2016) theorized that agricultural protection represents an effort by the political class to increase agricultural growth by improving national food security and minimizing food dependence on foreign countries. Rooted in the realist view of the world, the theory suggests that a state's concern about food dependence on foreign countries or about national food insecurity would be heightened as the extent of vulnerability to national food insecurity increases and as per capita income rises. In turn, concern about national food insecurity in a country is hypothesized to lead to growth in agricultural protection. In Akanegbu (2015), the pace of economic growth of Nigeria is best indicated by the trend of its gross domestic product (GDP) or gross national product (GNP).

The patterns of agricultural protection policies in Nigeria and other developing economies in Africa suggest that developing nations strongly subsidize agriculture (Olper, 1998). However, scholars have conflicting opinions about the impact of such political economy tool because poverty and other expected macroeconomic indexes are not commensurate with the claims of huge expenditures by the political class over the years. For instance, Inhwam (2008) and Barrette (1999) had argued that agricultural protection is capable of creating negative externalities to developing countries because agricultural protection distorts trades of agricultural products which some developing countries have a comparative advantage in producing. On the contrary, Goldin and Knudsen (1990) opined that since agriculture is a sector of comparative advantage for many developing countries now and for some time in future, agricultural protection does not materially impair their potentials for economic growth. Moon, Pino, and Asirvatham (2016) also support that protection could bring about agricultural growth in the economy.

To determine the relationship between agricultural growth and protection, some other relevant political economy factors or indicators are expected to guide the decision. Bratton and van de Walle (1994) viewed political economy variables as those factors taken into consideration as economic and political exigencies when analysing protectionism. Such political economy variables may include the state of food security or food selfsufficiency status; the contribution of foreign exchange earnings from the sector's export; general economic welfare to farm producers; GDP of the sector; budgetary allocation to the sector; and political or structural changes in the economy. In the same line of thought, Amin (1972) explained that different regime reflected varying economic and political interests. It is expected that a nation whose food supply is grossly dependent on import would be politically vulnerable. Pejout (2010) opined that food riots and violence became more prevalent in African cities following the rapid escalation of food prices in 2008 (Pejout, 2010) and this resulted in political instability and drove governments to re-analyse their agricultural policy. General economic welfare to farmers is also a political indicator that determines the demand push for protection from voters/farmers. It is expected that when the farmers are not making much of profit, their demand for protection may likely increase. Sometimes, it is suspected that political class purposively increases the agricultural bud get for protection or subsidies in order to gain political support during elections. In line with this, Bratton and Van De Walle (1994), opined that political class or elite mobilize political support by using their public position to distribute rent-seeking opportunities such as subsidies, interest free-loan, or grants. Nations' GDP appears to be a quick tool in the hands of politicians for measuring the progress of policies and programmes. The GDP situation during a specific period or policy regime may guide the political class on whether the sector needs promotion or not. The rise and growth of agricultural protection coincide with the long-term decline in the share of agricultural labour and in the share of agriculture from overall GDP (Binswanger and Deininger, 1997).

Empirically, data from CBN (2018), in the year 1960, agriculture contributed about $64 \%$ to the total GDP, however, in the 1970s, the contributions from agriculture to the GDP decreased to $48 \%$. Furthermore, the decrease proceeded to $20 \%$ in 1980 and $19 \%$ in 1985 respectively and has continued to show weakness till date.

By the opinion of Iwuchukwu and Igbokwe (2012), Nigeria's agricultural policies and programmes have undergone changes, especially in the post-colonial era. These changes according to Amalu (1998) have been a mere reflection of changes in government and administration. Amalu emphasized that these policies and programmes vary only in nomenclature and organizational network. Maybe no empirical research has bordered to investigate the claim that despite these policies and reforms, which gulped billions of tax-payers money, poverty and poor agricultural growth are still prevailing.

Olawepo (2010) opined that income is generally low from agricultural production. Also, International Fund for Agricultural Development (IFAD; 2016, NBS; 2017) reported that despite all these many efforts, poverty is still widespread in the country and has been on increase. Also, CBN (2018) reported that the share of GDP from agriculture has remained between $11 \%$ and $21 \%$ from 1980 to date. In any country where government's intervention is promulgated in any sector, questions of accountability and appraisal arise of to what extent or degree does government support such policy, and how much has the policy contributed to the growth of the sector?

The main objective of this study was to examine the 
impact of agricultural protection on agricultural growth in Nigeria. The specific objectives were to (i) estimate the level of agricultural protection in Nigeria; (ii) determine the effects of agricultural protection on agricultural growth, and (iii) analyse the causal relationship between agricultural protection and agricultural growth in Nigeria. The null hypothesis tested was that agricultural protection does not have a statistically significant impact on agricultural growth in Nigeria.

\section{DATA AND METHODS}

\section{Analytical framework}

Studies on agricultural protection or other political economy issues have employed alternative measurement concepts which differ in their meanings and in terms of their uses and degree of complexity. However, where the effects of government policies are not directly translated into domestic prices, these measures would provide only a partial indication of the extent of government's protection interventions. The most simple and widely used measurement of the protection level is the nominal rate of protection (NRP) and the nominal protection coefficient (NPC) (Tyers and Anderson, 1992; Krueger, Schiff and Valdés, 1991). Amin (1996) puts that Nominal protection coefficient (NPC) is the ratio of producer price (Pi) to the border price (Pf) with adjustment made for transport, storage, and other costs.

Also, the relationship between agricultural GDP and agricultural protection is akin to output and input relation. While government stimulate agricultural production with some protection policy instruments such as fertilizer subsidy, direct transfer, distribution of improved seedling, etc, it is expected that these investment will transform into increase in GDP.

The effect of agricultural protection on agricultural growth was analysed in the standard growth accounting framework. The validity or strength of the multiple linear regression method used in this study is based on the Gauss-Markov assumptions in which the dependent (GDP) and independent variables (political economy/macroeconomic variables) are expected to be linearly correlated, with the estimators $\left(\beta_{0}, \beta_{1}, \beta_{2}, \beta_{3}, \beta_{4}\right.$, $\beta_{5}$ ) being BLUE with an expected value of zero i.e. $\mathrm{E}(\varepsilon)=$ 0 , which implies that on average the errors cancel out each other.

\section{Model specification}

The coefficients of the protection level in the agricultural sector are widely estimated using the nominal protection coefficient (NPC). According to De Gorter and Tsur, (1991), Krueger, Schiff, and Valdés, (1991), the most simple and widely used measurement of the price wedge is the nominal rate of protection (NRP) and the nominal protection coefficient (NPC) (Krueger, Schiff and Valdés, 1991; Miller and Anderson, 1992 and Arene, 2008). The level of protection estimation equation is given in Eq. 1.

$$
N P C=\frac{P D}{P W}
$$

Where: PD Domestic Producer Price; PW World price.

The measurement concepts refer to the protection levels for a single agricultural commodity, but these can easily be aggregated to reflect overall protection to the agricultural sector. Secondly, to represent the relationships between agricultural output and its political economy determinants, the standard model of economic growth as applied by Owutuamor and Arene, 2018 was followed. In the same line, Solow (1956) growth model was adopted in which the output of agricultural sector, usually measured by the gross domestic product (GDP) of the sector, is represented in the production function where its growth depends on a number of factors $X_{1}, X_{2}, X_{3} \ldots X_{n}$. The function is shown in equation 2 .

$Y=f\left(X_{1}, X_{2}, X_{3}, X_{4}, X_{5}\right)$

Where: $Y$ output and $X_{1}, X_{2}, X_{3}, X_{4}, X_{5}$, factors that determine the rate of output. To account for time factor in the model, according to Mankiw, Romer and Weil (1992), output i.e. Agricultural GDP growth, became a function of government income (measured by agricultural budget), foreign direct investment (FDI), amount of protection in the sector (measured by nominal protection coefficient, NPC), policy structure changes and form of government at time $(t)$.

$Y_{t}=f\left(X_{1(t)} \cdot X_{2(t)} \cdot X_{3(t)} \cdot X_{4(t)} \cdot X_{5(t)}\right)$

Assuming there is a steady state, say a linear relationship, as seen in standard output models; output is estimated by multiple linear equations in the linear form in Eq. 3, which formed the basis for the estimation of the model in this study. This study is also based on the assumption that there may be other influential factors affecting growth but this study is only restricted to political economy variables as indicators for quick and easy policy considerations. In order to establish the mathematical function of this model, the intercept $\beta_{0}$, measure of error term $\varepsilon$ and parameters of estimations $\beta_{1,2,3 \ldots n}$ are added in Eq. 4.

$$
\begin{aligned}
& Y_{t}=\beta_{0}+\beta_{1} X_{1(t)}+\beta_{2} X_{2(t)}+\beta_{3} X_{3(t)}+\beta_{4} X_{4(t)}+ \\
& \beta_{5} X_{5(t)}+\varepsilon
\end{aligned}
$$

\section{Choice of variables}

The choice of political economy variables that could affect agricultural protection was conceptualised in line with the views of Moon, Pino, and Asirvatham (2016) which theorized that agricultural protection represents an effort by the political class to increase agricultural growth. Rooted in this realist view of the political economy relationship, the study selected only variables assumed to have strong political and economic implications for agricultural policy. These variables stand as indicators in the hands of the political class which guide their political and economic decisions on the timing, budgeting and degree of protection in the sector.

In line with this conceptualisation, Bratton and van de Walle (1994) viewed political economy variables as those factors taken into consideration as economic and 
political exigencies when analysing protectionism. Such political economy variables may include the state of food security or food self-sufficiency status; general economic welfare or GDP of the sector; bud getary allocation to the sector; and policy structural changes in the economy. In the same line of thought, Amin (1972) explained that different regime reflected varying economic and political interests. Also, in Akanegbu (2015), the pace of economic growth of Nigeria is best indicated by the trend of its gross domestic product (GDP). Following this, the model for the regression as given in Eq. 4 are specified thus:

$Y$ GDP Gross Domestic Product, the dependent variable which represents the GDP share to agricultural sector; an indicator or tool for making quick political decisions for adjustments or performance assessment in the economy.); $X_{1}$ Nominal Protection Coefficient (NPC), used as proxy for measuring the degree of agricultural price protection in the economy;

$X_{2}$ Foreign Direct Investment (FDI) share to agricultural sectors which represents the economic and political will of individuals to invest in the sector);

$\mathrm{X}_{3}$ budgetary allocation to agricultural sector which is an indicator for political willingness of the ruling class to motivate or invest in the economy;

$X_{4}$ policy structure changes (protection 1, no protection $0)$;

$X_{5}$ form/type of government (civilian 1, military 0);

$\beta_{0}$ Intercept;

$t$ Time series;

$\varepsilon$ Stochastic error term; and

$\beta_{1}, \beta_{2}, \beta_{3}$ Estimation coefficients.

Apriori Expectations: On apriori, the following relationship in line with Eq. 2 as expected is shown in Eq. 5 .

$G D P=f(N P C)$

In order to improve the linearity of the equation, Owutuamor and Arene, (2018) followed same as advised in Obansa and Maduekwe (2013) that there is need to log-linearize all the incorporated variables in order to avoid multicollinearity and to revert the mean generating process. As such, natural log is introduced into Eq. (4), thereby giving the econometric model in (Eq. 6).

$\ln Y_{t}=\beta_{0}+\ln \beta_{1} X_{1(t)}+\ln \beta_{2} X_{2(t)}+\ln \beta_{3} X_{3(t)}+$

$\ln \beta_{4} X_{4(t)}+\ln \beta_{5} X_{5(t)}+\varepsilon$

The model's empirical strategy is based on these apriori expectations shown in Eq. 7.

$\beta_{0}>\beta_{1}>\beta_{2}>\beta_{3}>\beta_{4}>\beta_{5}$

The empirical model specified in Eq. 7 was estimated from literature. First, the observed variables, $X_{1}-X_{5}$ are fully accounted for in the equations based on the assumption that agricultural growth does not happen without some factors acting on it (Inhwan, 2008; Moon, Pino, and Asirvatham, 2016). However, it is expected that many factors could affect the growth of the sector but this study was limited to political economy perspective.
The reason was to specifically $\mathrm{x}$-ray the dynamics of government's interventions in the sector. In line with the assumptions, Bratton and van de Walle (1994) opined that political economy variables are those factors taken into consideration as economic and political exigencies. Also, it is expected that increase in NPC in the economy will motivate growth in the sector. Increase in FDI share to agricultural sectors will increase the volume of production and growth. Increase in budgetary allocation to agricultural sector will spur investment and growth. Also, when the policy structure changes from exploitation or liberalization to protection policy, many young investors would feel protected and invest more. Finally, it is expected that government under democracy would attract more investment and growth in the sector.

\section{Hypotheses}

The following two hypotheses were tested in the study: $\mathrm{Ho}_{1}$ : agricultural protection level does not have a significant effect on agricultural growth in Nigeria; and $\mathrm{Ho}_{2}$ : there is no causal relationship between agricultural protection level and agricultural growth. The null hypotheses, $\mathrm{H}_{0}$ were tested using the F-statistic at the five percent $(5 \%)$ level of significance. The calculated $F$ value (Fcal) was compared to the critical value of $\mathrm{F}$ (F-tab). Usually, if the value of the F-cal is greater than that of the F-tab at the 5\% level of significance; the null hypothesis is rejected but if otherwise, it is accepted. The F-statistics formula is given as Eq. 8 .

$F=\frac{\frac{R^{2}}{K}-1}{\frac{1-R^{2}}{N-K}}$

\section{The Study Area}

The study area is officially known as the Federal Republic of Nigeria, but here often referred to as Nigeria. The major exports of the country are: crude oil (petroleum), natural gas, cashew nuts, skin and fur, tobacco, cocoa, cassava, rubber, food, live animals, aluminium alloys and other solid minerals, (CIA World Factbook 2018) while major imports are refined petroleum products, wheat, rice, sugar, herbicides, fertilizers, chemicals, vehicles, aircraft parts, vessels, vegetable products, processed food, beverages, spirits and vinegar, equipment, machines, and tools (NBS 2015). Despite its considerable agricultural resources, Nigeria is still a net importer of food and agricultural products in general (USAID 2009) and as such the agricultural sector has been one of the least attractive sectors (Owutuamor and Arene, 2018) and has lost its leading contribution to Nigeria's GDP (CBN 2018; FAO 2012).

\section{Data Specification}

This work made use of secondary data. The annual time series data of agricultural output, measured by the share of agriculture to GDP, and FDI inflows into the sector were collected from CBN, spanning from 1980-2015 while 2016 was extrapolated. Also, NPC was calculated from annual data of domestic price collected from FAOSTAT and World price collected from World Bank. This study covering a 37-year period, spanning from 1980 to 2016 
employed descriptive statistics aided by the use of Microsoft Excel and inferential statistics in the form of the econometric regression methods of the multiple linear regression and Granger causality test were applied as the estimation technique in evaluating the relationships and causality between the dependent variable (agricultural growth) and the political economy variables (agricultural protection level, foreign direct investment inflows to agriculture, Gross Domestic Product (GDP) inflows from the agricultural sector into the economy, political structure changes in national policy reforms and form of government in power).

The regression equation was estimated after carrying out pre-estimation tests for stationarity in order to avoid multicollinearity of explanatory variables. To eliminate the presence of autocorrelation in the model, this study applied the Augmented Dickey-Fuller (ADF) test to detect the stationarity of the variables at the $5 \%$ level of significance and also identify the order of integration of the variables in the model.

For the objective one, the level of protection in agriculture was estimated using the NPC model. For objective two, the effect of protection (as estimated in objective one) and other political economy tools on agricultural growth were determined using multiple linear regression with SPSS. For objective three, the causal relationship between agricultural growth and the independent variables (political economy variables) were determined using Granger causality test with Eview software.

\section{RESULTS AND DISCUSSION}

\section{Pre-Estimation Techniques}

Before the main analyses were conducted, the set of data was tested for unit root in the study. ADF was used to carry out the test under its traditional conditions, hypotheses and decision rules as adopted by Nwosu and Okafor (2014). In a related study, Njoku, Chigbu and Akujobi (2015) also adopted the use of unit root test on some residuals using the ADF test. The variables were further tested for endogeneity and corrections made. Also, the variables were further subjected to cointegration test to check for long-term association.

The decision rule showed that the prob (t-stat) $>0.05$ which implied that the null hypothesis of no integration be rejected and we, therefore, concluded that the variables in the model have long-term relationship.

To eliminate the presence of autocorrelation in the model, this study applied the Augmented Dickey-Fuller (ADF) test to detect the stationarity of the variables at the $5 \%$ level of significance and also identify the order of integration of the variables in the model. The ADF test was based on the following regression in Eq. (8).

$\Delta \mathrm{Y}_{\mathrm{t}}=\alpha+\beta \mathrm{Y}_{\mathrm{t}-1}+\delta \mathrm{t}+\Sigma \varsigma \mathrm{k} \Delta \mathrm{Y}_{\mathrm{t}-\mathrm{kPk}=1}+\varepsilon$

$H 0: \delta=0$ ( $Y$ has no unit root $)$;

$H 1: \delta \neq 0$ ( $Y$ has unit root $)$

Where:

$Y$ Variable tested (lnGDP, $\ln F D I, \ln B U D G E T$, and so on)

$\alpha$ Intercept (constant term)

$\delta t$ Coefficient on a time trend

$\beta$ Parameter of the variable in regression

$P$ Lag order

$\Delta$ Difference operator.

The Johansen (1991) co-inte gration method was used to test for long-term relationship between the variables. This involves looking for linear combinations of I in Eq. (9) time series that are stationary in the order I(1). This procedure focuses on the rank of the П-matrix as shown in Eq. (9).

$$
\Delta Z_{t}=\alpha+\Pi Z t-1+\Sigma \Gamma 1 \Delta Z t-i P-1 i=1+\varepsilon
$$

Where:

$Z \mathrm{n} \times 1$ vector of variables that are integrated of order one, often denoted as $\mathrm{I}(1)$;

$\Pi$ co-efficient matrix ;

$\Gamma$ number of co-integrating relationships.

Such that if the $\Pi$-matrix has reduced rank, the endogenous variables depicted by $Z$ are co-integrated, with $\alpha$ as the co-integrating vector.

However, if the variables are stationary in levels, П would have full rank.

The results of the ADF and cointegration tests are shown in Tables 1 and 2. The result shows that all the variables were stationary at their first difference (i.e. 1(1)).

Table 1: ADF unit root test result

\begin{tabular}{lllllll}
\hline Variables & ADF Sats & $\begin{array}{l}\text { Critical } \\
\text { Value } \\
1 \%\end{array}$ & $\begin{array}{l}\text { Critical } \\
\text { Value } \\
5 \%\end{array}$ & $\begin{array}{l}\text { Critical } \\
\text { Value } \\
10 \%\end{array}$ & $\begin{array}{l}\text { Order } \\
\text { Integration }\end{array}$ & of \\
\hline 1.GDP & -6.192236 & -3.639407 & -2.951125 & -2.614300 & $1(1)$ & semark \\
2.NPC & -5.890904 & -3.639407 & -2.951125 & -2.614300 & $1(1)$ & stationary \\
3.FDI & -11.91513 & -3.639407 & -2.951125 & -2.614300 & $1(1)$ & stationary \\
4.BUDGET & -5.550498 & -3.639407 & -2.951125 & -2.614300 & $1(1)$ & stationary \\
5.POCH & -3.657007 & -3.657007 & -2.967767 & -2.622989 & $1(1)$ & stationary \\
6.GOVFORM & -6.692878 & -3.632900 & -2.948404 & -2.612874 & $1(1)$ & stationary \\
\hline
\end{tabular}

Source: computed output with e-views. 
Table 2: Johansen cointegration test result

\begin{tabular}{llll}
\hline $\begin{array}{l}\text { Eigen } \\
\text { Value }\end{array}$ & $\begin{array}{l}\text { Likelihood } \\
\text { Ratio (Lr) }\end{array}$ & $\begin{array}{l}\text { Critical } \\
\text { Value 5\% }\end{array}$ & $\begin{array}{l}\text { Hypothesized No } \\
\text { Of C.E }\end{array}$ \\
\hline 0.734822 & - & 46.23142 & None** \\
0.673258 & 1464.734 & 40.07757 & At most 1 \\
0.581074 & 1446.277 & 33.87687 & At most 2 \\
0.5410732 & 1431.921 & 25.58434 & At most $3^{* *}$ \\
0.458023 & 1419.082 & 21.13162 & At most $4^{* *}$ \\
0.363664 & 1408.976 & 14.26460 & At most $5^{*}$ \\
0.090478 & 1401.517 & 3.841466 & At most $6^{* *}$ \\
\hline
\end{tabular}

*(**) denotes rejection of the hypothesis at 5 percent (1 percent) significance levels. L.R. test indicates 5 cointegration equations (s) at 5 percent level. C.E represents Cointegrating Equations

Source: computed output with e-view

The result in the Table 2 confirm that the variables were co-integrated in the long-run at the same rate by the normalized co-integration coefficient with the highest log likelihood in absolute term.

\section{Estimates of Agricultural Protection Coefficient in Nigeria}

The level of protection in the agricultural sector in Nigeria (Table 3) shows an unsteady trend. In general, the average coefficient of protection measured from selected major staple food and agricultural export commodities in Nigeria shows that the mean value was $31.8 \%$, the minimum was $19.6 \%$ (2009) while the maximum was $53.2 \%$ (2000). This suggests that Nigeria protected agricultural sector. This result is in line with previous studies (Olper, 1998) which states that the patterns of agricultural policies in Africa suggest that developing nations strongly subsidize or protect agriculture.

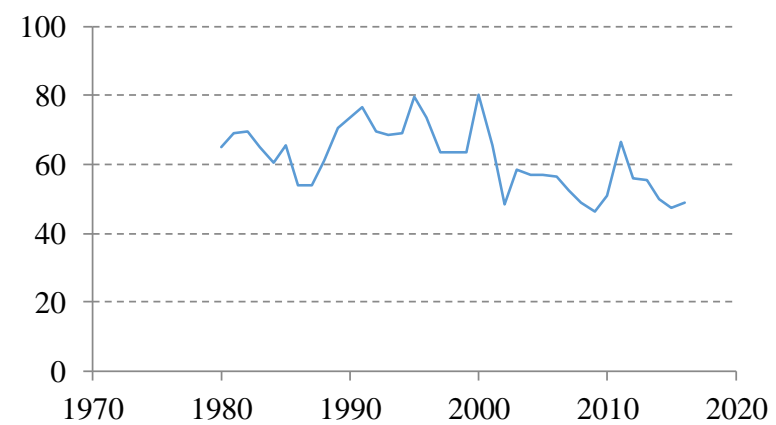

Figure 1: Graphical presentation of protection level in agriculture from 1980 to 2016.

Source: Author's Computation, 2018.

\section{Effects of Agricultural Protection and Other Political Economy Variables on Agricultural Growth}

The results in Table 4 showed that about $33.5 \%$ variations of agricultural growth were explained by variation in the selected political economy variables which was statistically significant $(\mathrm{p}<0.01)$. This means that the variables specified in the model significantly affected the growth in the agricultural sector. As such, the null hypothesis which states that agricultural protection level does not have a significant effect on agricultural growth in Nigeria be rejected, and the alternative hypothesis accepted.
The specific political economy factors that had significant effects on agricultural growth were agricultural protection level, nation's budgetary allocation to Agriculture and form of governance. These political economy variables were discussed below:

\section{Agricultural protection level and agricultural growth}

This research reveals that agricultural protection level had negative significant effect on agricultural growth in Nigeria. For every one unit change in agricultural protection level, there is a change of -280 units showing a decrease in the agricultural growth measure - GDP share to agriculture. This is related to other findings by Saibu and Keke (2014) and Usman and Arene (2014), who inferred that some macroeconomic variables move in opposite direction. In related studies, Barrette (1999) and Inhwam (2008) had argued that agricultural protection is capable of creating negative externalities to developing countries. Also, Ubogu (1988) conclude that a liberal trade regime with low tariffs and without quotas up to 1973 translated to export-led growth in the world economy and relative stability in Nigeria's export earnings and inflow of foreign capital.

The policy implication of this result is that funding meant for agriculture should rather be used for investment in other areas of the sector other than offering protection to the farmers through subsidies and incentives. The sector is in urgent need for massive investment under liberal trade since this study has shown that protecting the sector would do more harm than good. This result has also revealed that food policy involves not only activities in agricultural production but also includes feeding the industries with raw materials, food processing and manufacturing to reduce post-harvest losses, distribution and marketing of value-added products and, trade and consumption that are capable to spur industrialization.

\section{Budgetary allocation to agriculture}

This research reveals that agricultural budgetary allocation had a positive and significant impact on agricultural growth in Nigeria. For every one unit change in agricultural budget, there was a positive change of $2.99 \%$ in the GDP share to agriculture showing a significant increase in the agricultural growth. It is logical and expected that a unit increase in budgetary allocation to agriculture causes a positive impact on the growth and productivity of agriculture. This result is in line with that 
of Asghar, Hussain and Rehman (2012), Ogujiuba and Ehigiamusoe (2013). Keynes theory on public expenditure and economic growth regards public expenditures as an exogenous factor which can be utilized as a policy instruments promote economic growth. From the Keynesian's point of view, public expenditure can contribute positively to economic growth.

Table 3: Nominal protection of agriculture in Nigeria from $1980-2016$.

\begin{tabular}{|c|c|c|c|c|c|c|c|c|c|}
\hline YEAR & NPC cocoa & $\begin{array}{c}\text { NPC } \\
\text { cotton }\end{array}$ & $\begin{array}{r}\text { NPC } \\
\text { maize }\end{array}$ & $\begin{array}{r}\mathrm{NPC} \\
\text { palm oil }\end{array}$ & $\begin{array}{r}\text { NPC } \\
\text { rice } \\
\end{array}$ & $\begin{array}{r}\text { NPC } \\
\text { rubber }\end{array}$ & $\begin{array}{r}\text { NPC } \\
\text { wheat }\end{array}$ & $\begin{array}{r}\text { NPC } \\
\text { Average }\end{array}$ & $\begin{array}{r}\text { NPR } \\
\text { Average }\end{array}$ \\
\hline 1980 & 1.7 & 2.2 & 0.6 & 0.9 & 1.1 & 1.1 & 1.0 & 1.2 & 20 \\
\hline 1981 & 1.9 & 2.2 & 0.6 & 1.0 & 1.1 & 1.1 & 1.0 & 1.3 & 30 \\
\hline 1982 & 2.0 & 2.1 & 0.7 & 1.0 & 1.1 & 1.1 & 1.0 & 1.3 & 30 \\
\hline 1983 & 1.8 & 2.1 & 0.6 & 1.0 & 1.1 & 1.1 & 1.0 & 1.2 & 20 \\
\hline 1984 & 1.5 & 2.1 & 0.6 & 1.0 & 1.1 & 1.1 & 1.0 & 1.2 & 20 \\
\hline 1985 & 1.4 & 2.5 & 0.8 & 0.9 & 1.1 & 1.1 & 1.0 & 1.2 & 20 \\
\hline 1986 & 1.3 & 2.5 & 0.9 & 1.0 & 1.1 & 1.1 & 1.0 & 1.3 & 30 \\
\hline 1987 & 1.7 & 2.0 & 1.0 & 1.0 & 1.1 & 1.0 & 1.0 & 1.3 & 30 \\
\hline 1988 & 2.0 & 2.2 & 1.0 & 1.0 & 1.1 & 1.0 & 1.0 & 1.3 & 30 \\
\hline 1989 & 2.8 & 2.1 & 1.0 & 1.0 & 1.1 & 1.0 & 1.0 & 1.4 & 40 \\
\hline 1990 & 3.0 & 2.1 & 1.0 & 1.0 & 1.1 & 1.0 & 1.0 & 1.5 & 50 \\
\hline 1991 & 3.1 & 2.2 & 1.0 & 1.0 & 1.1 & 1.1 & 1.0 & 1.5 & 50 \\
\hline 1992 & 2.6 & 2.2 & 1.0 & 1.0 & 1.1 & 1.1 & 1.0 & 1.4 & 40 \\
\hline 1993 & 2.5 & 2.2 & 1.0 & 1.0 & 1.1 & 1.1 & 1.0 & 1.4 & 40 \\
\hline 1994 & 2.7 & 2.1 & 1.0 & 1.0 & 1.3 & 1.1 & 1.0 & 1.5 & 50 \\
\hline 1995 & 3.3 & 2.2 & 1.0 & 1.0 & 1.0 & 1.0 & 1.0 & 1.5 & 50 \\
\hline 1996 & 2.8 & 2.3 & 1.0 & 1.0 & 1.0 & 1.0 & 1.0 & 1.4 & 40 \\
\hline 1997 & 2.3 & 2.1 & 1.0 & 1.0 & 1.0 & 1.1 & 1.0 & 1.4 & 40 \\
\hline 1998 & 2.0 & 2.4 & 1.0 & 1.0 & 1.0 & 1.1 & 1.0 & 1.4 & 40 \\
\hline 1999 & 2.2 & 2.2 & 1.0 & 1.0 & 1.0 & 1.1 & 1.0 & 1.4 & 40 \\
\hline 2000 & 3.3 & 2.3 & 1.0 & 1.0 & 1.0 & 1.1 & 1.0 & 1.5 & 50 \\
\hline 2001 & 2.3 & 2.3 & 1.0 & 1.0 & 1.0 & 1.1 & 1.0 & 1.4 & 40 \\
\hline 2002 & 1.2 & 2.1 & 1.0 & 1.0 & 1.0 & 1.1 & 1.0 & 1.2 & 20 \\
\hline 2003 & 1.8 & 2.3 & 1.0 & 1.0 & 1.0 & 1.0 & 1.0 & 1.3 & 30 \\
\hline 2004 & 1.8 & 2.1 & 1.0 & 1.0 & 1.0 & 1.1 & 1.0 & 1.3 & 30 \\
\hline 2005 & 1.7 & 2.2 & 1.0 & 1.0 & 1.0 & 1.0 & 1.0 & 1.3 & 30 \\
\hline 2006 & 1.7 & 2.2 & 1.0 & 1.0 & 1.0 & 1.0 & 1.0 & 1.3 & 30 \\
\hline 2007 & 1.5 & 2.1 & 1.0 & 1.0 & 1.0 & 1.0 & 1.1 & 1.3 & 30 \\
\hline 2008 & 1.3 & 2.1 & 1.0 & 1.0 & 1.1 & 1.0 & 1.1 & 1.2 & 20 \\
\hline 2009 & 1.0 & 2.2 & 1.0 & 1.0 & 1.1 & 1.0 & 1.1 & 1.2 & 20 \\
\hline 2010 & 1.5 & 2.0 & 1.0 & 1.0 & 1.1 & 1.0 & 1.1 & 1.2 & 20 \\
\hline 2011 & 2.4 & 2.2 & 1.0 & 1.0 & 1.0 & 1.0 & 1.0 & 1.4 & 40 \\
\hline 2012 & 1.7 & 2.1 & 1.0 & 1.0 & 1.0 & 1.0 & 1.0 & 1.3 & 30 \\
\hline 2013 & 1.7 & 2.1 & 1.0 & 1.0 & 1.0 & 1.0 & 1.0 & 1.3 & 30 \\
\hline 2014 & 1.3 & 2.1 & 1.1 & 1.0 & 1.0 & 1.0 & 1.1 & 1.2 & 20 \\
\hline 2015 & 1.1 & 2.2 & 1.0 & 1.0 & 1.0 & 1.0 & 1.1 & 1.2 & 20 \\
\hline 2016 & 1.2 & 2.1 & 1.1 & 1.0 & 1.0 & 1.0 & 1.2 & 1.2 & 20 \\
\hline Min & & & & & & & & 1.2 & 20 \\
\hline $\operatorname{Max}$ & & & & & & & & 1.5 & 50 \\
\hline Mean & & & & & & & & 1.3 & 30 \\
\hline
\end{tabular}

NPC means Nominal Protection Coefficient. Source: Author's Computation, 2018.

Table 4: Parameter estimates of effects of Political Economy Variables on Agricultural Growth

\begin{tabular}{llll}
\hline Political Economy Variables & Parameters & Coefficients & t-ratio \\
\hline (Constant) & $\beta_{0}$ & $-(.443)$ & .549 \\
NPC & $\mathrm{X}_{1}$ & $-.280(.061)$ & $-1.786^{*}$ \\
FDI & $\mathrm{X}_{2}$ & $-.126(.583)$ & -.826 \\
BUDGET & $\mathrm{X}_{3}$ & $510(.193)$ & $2.987^{* * *}$ \\
PCH & $\mathrm{X}_{4}$ & $-.005(1.548)$ & -.030 \\
GOVFORM & $\mathrm{X}_{5}$ & $-.371(2.090)$ & -2.216
\end{tabular}

Key: $* * *, * *, *$ represent $1 \%, 5 \%$ and $1 \%$ levels of significance respectively. Figures in parentheses represent standard errors. Source: Authors' computation, 2018. 
The result obtained in the study suggests that agricultural budgets have positive impact on agricultural growth in Nigeria. This suggests that Nigeria has to encourage increased investment and budgetary allocation to the sector. If the investment and budget are increased in the sector, it could support a vibrant agricultural sector capable of ensuring the supply of raw materials for the industrial sector as well as providing gainful employment for the teeming population. It will also address the economic problems of rural poverty which is rampant and reduce dependence on oil and food importation. This call needs urgent attention especially now that Nigeria's poverty rate is reportedly alarming. However, if the agricultural sector is encouraged with the introduction of improved technology so as to diversify the economic base and reduce dependence on oil revenue in the bid to return the economy to the path of self-sustaining growth and industrialization, then it will enhance economic prosperity. Zietz and Valdes (1993) also identified that the size of government's budget is likely to shift the supply curve of protection, adding that it's particularly true when agricultural protection is provided through subsidies or incentives. Therefore, caution should be taken to invest the funding in areas that require investment rather than agricultural protection.

\section{Causal Relationship between Agricultural Protection Level and Agricultural Growth}

The null hypothesis which states that there is a causal relationship between agricultural protection level and agricultural growth was tested using Granger causality test and the result is presented thus:

Table 5: Parameter Estimates for short run Pair Wise Granger Causality Tests between level of agricultural protection and growth in the sector.

\begin{tabular}{lcc}
\hline Null Hypothesis & F-Statistic & Prob. \\
\hline GDP does not & 14.9167 & 0.0005 \\
Granger Cause NPC & & \\
NPC does not & 11.8675 & 0.0016 \\
Granger Cause GDP & & \\
\hline
\end{tabular}

Sample: 1, 36, Lags: 1

Source: Authors Computation, 2017.

The result showed that the null hypotheses contained in Table 5 were rejected. These, therefore, mean that GDP share from agriculture causes significant changes in agricultural protection and that in the short run too, protection level in agriculture is significant in causing changes in GDP growth share from agriculture. This is related to that of Obansa and Maduekwe (2013), Oloyede (2014), and Owutuamor and Arene (2018) that agricultural growth can be induced by a macroeconomic variable. Since GDP can be used to measure general economic welfare in an economy (Gardner, 2012), Bratton and van de Walle (1994), opined that political class or elite mobilize political support by using their public position to distribute rent-seeking opportunities such as subsidies, interest free-loan, or grants. This means that when the GDP is low, politicians are likely to increase agricultural protection as a way of buying support from farmers who are also the majority of the voters.
Paradoxically, the increase in agricultural protection causes a negative change in the sector's GDP as seen in the regression in Table 5.

\section{CONCLUSIONS}

This study was carried out to statistically analyse the impact of agricultural protection on agricultural growth, measured by agricultural output (GDP) in Nigeria. The variables were logically restricted to political economy indicators as tools in the hands of the political class for managing the economy of the nation. It describes the trends in agricultural growth and protection level in agriculture and empirically analysed the effects of agricultural protection level on gross domestic product inflows from agricultural sector into the economy and other political economy cum macroeconomic variables such as Foreign Direct Investment (FDI) share to the agricultural sector which represents the economic and political will of individuals to invest in the sector; budgetary allocation to agricultural sector which is an indicator for political willingness of the ruling class to motivate or invest in the economy; political structure changes whose dummy nature was vectorized into protection as 1 , and no protection as 0 ; and form/type of government (also put as civilian 1, military 0).

The empirical results show that about 34 percent of the total variation in agricultural growth can be explained by agricultural protection and other political economy variables considered in the model, whereas less than 66 percent is accounted for by the error term and other variables not included in the political economy model. Although there was a negative relationship between agricultural growth and protection in agriculture, this was significant. It also reveals that agricultural protection had a positive and significant impact on agricultural growth in Nigeria between 1980 and 2016.

The findings in this study suggest strong policy implications which are recommended as thus: Nigerian government should rearrange its food policies to position agriculture in a more liberalized commercial form as a serious business rather than a means of addressing farmer's demand for subsidies and price effects. The government should also increase its budgetary allocation to the sector for the purpose of embarking on the massive construction of agro-industries, silos, and other important capital projects that would cover many other aspects of agriculture such as processing, storage, marketing, industrialization, etc.

\section{Acknowledgement}

The authors acknowledge the useful comments from members of the Department of Agricultural Economics, University of Nigeria, Nsukka during the seminar sessions.

\section{REFERENCES}

AKANEGBU, B.N. (2015). Agricultural price distortions and their effects on the Nigerian economy: An Empirical Analysis. European Journal of Research in Social Sciences Vol. 3 No. 1, 2015. ISSN 2056-5429. 
AMALU, U.C. (1998). Agricultural Research and Extension Delivery systems in Sub-Saharan Africa. Calabar. University of Calabar Press.

AMIN, A.A. (1996). The effects of exchange rate policy on Cameroon's agricultural competitiveness. African Economic Research Consortium. Research paper 42.

ANDERSON, K., HAYAMI. Y. and HONMA M. (1986). The Growth of Agricultural Protection: in Kym Anderson and Yujiro Hayami (eds.). The Political Economy of Agricultural Protection, Sydney: Allen and Unwin. Sydney.

ARENE C.J. (2008). Economic analysis of agricultural and rural development projects (planning, appraisal, implementation and evaluation. Prize Publishers, Enugu Nigeria.

ASGHAR, N., HUSSAIN, Z. and REHMAN, H. (2012). The Impact of Government Spending on Poverty Reduction: Evidence from Pakistan (1972-2008). African Journal of Business Management, 6(3), 845-853.

BALISACAN, A. and ROUMASSET J.A. (1987). Public Choice of Economic Policy: The Growth of Agricultural Protection. W. Archive, 123: 232-248.

BARETTE, C.B. (1999). Micro-economics of the development paradox on the political economy of food price policy. Agricultural Economics 20(1999) 159-172.

BIGMAN, D. (1985). Food Policies and Food Security under Instability: Modeling and Analysis, Lexington, MA: D. C. Heath and Company.

BINSWANGER, H. P. and DEININGER. K. (1997). Explaining agricultural and agrarian policies in developing countries. Journal of Economic Literature, Vol XXXV (December): 1958-2005.

BRATTON, M. and DE WALLE V. N (1994). Neopatrimonial Regimes and political transitions in Africa. World Politics.46 (4), 453-489. DOI: https://doi.org/10.2307/2950715

CIA World Factbook (2015). The World Factbook. Retrieved November 26, 2015, from www.cia.gov.

Civil Society Coalition for Poverty Eradication (CISCOPE; 2009). Agricultural Expenditures: Budget Tracking/Investment Analysis of Agricultural Sector in Nigeria (2000-2008). Report Submitted to Voices for Food Security, Nigeria.

DE GORTER, H. and TSUR, Y. (1991). Explaining price bias in world agriculture: The calculus of support maximi zing politicians. American Journal of Agricultural Economics, 73:1244-54. DOI: https://doi.org/10.2307/1242452

FAO. (2012). Foreign Agriculture Investment Profile Nigeria. Food and Agriculture Organization (FAO) Investment Policy Support. Retrieved February 16, 2016, from http:// www.fao.org/fileadmin/user_upload/tcsp/docs/Nigeria_C ountry_Profile_FINAL.pdf

GARDNER, B. (1992). Changing Economic Perspectives on the Farm Problem. Journal of Economic Literature Vol XXX (March): 62-101

GOLDIN, I. and KNUDSEN, O. [ED]. (1990). Agricultural Trade Liberalization: Implication for developing countries. Paris OECD and World Bank.

GRAIS, W., DE MELO, J., and URATA, S. (1986). A general equilibrium estimation of the reduction of tariffs and quantitative restrictions in Turkey in 1978. In Thirukodikaval Srinivasan, John Whalley, (Eds.), General equilibrium trade policy modeling. Cambridge, MA.

INHWAM, J. (2008). Determinants of Agricultural Protection in Industrial Countries. An Empirical Bulletin, 17 (1) 1-11.

International Food and Agricultural Development [IFAD]. (2016). Poverty in Rural Nigeria. www.ruralpovertyportal.org/country/home/tags/nigeria/I

FAD.

IWUCHUKWU, J .C. and IGBOKWE, E.M. (2012). Lessons from Agricultural Policies and Programmes in Nigeria. Journal of Law, Policy and Globalization. www.iiste.org ISSN 2224-3240 (Paper) ISSN 2224-3259 (Online) Vol 5, 2012.

KRUEGER, A. O., SCHIFF, M. and VALDES, A. (1991), The Political Economy of Agricultural Pricing Policies, Vol. I-V, John Hopkins University Press.

MOON, W., PINO, G., and ASIRVATHAM, J. (2016). Agricultural protection, domestic politics, and international political economy: what is the role of the state in explaining agricultural protection? Selected paper prepared for presentation at the Agricultural and Applied Economics Association's 2016 Annual Meeting, Boston, MA, July 31 - Aug 2, 2016

OBANSA, S. A., and MADUEKWE, I. M. (2013). Agriculture Financing and Economic Growth in Nigeria. European Scientific Journal, 9(1), 168-204. ISSN: 1857 7431 (Online). Retrieved from http://eujournal.org/index.php/esj/article/viewFile/702/75 $\underline{0}$.

OGUJIUBA, K. K. and EHIGIAMUSOE, K. (2013). Capital budget Implementation in Nigeria: Evidence from the 2012 Capital Budget. Contemporary Economics 24(10), 299-314. DOI: 10.5709/ce.1897-9254.147

OKUMADEWA, F. (1997). Poverty and income in Nigeria: Measurements and Strategies for reform: A Paper Presented at the Vision 2010 Workshop, Abuja.

OLADIPO, O. S. (2010). Does Saving Really Matter for Growth in Developing Countries? The Case of a Small Open Economy. The International Business and Economics Research Journal, Vol. 9, Iss. 4: 87-94. DOI: https://doi.org/10.19030/iber.v9i4.556

OLOYEDE, B. B. (2014). Impact of Foreign Direct Investment on Agricultural Sector Development in Nigeria (1981-2012). Kuwait Chapter of Arabian Journal of Business and Management Review, 3(12), 14-24. DOI: $\underline{10.12816 / 0018804 .}$

OLPER, A. (1998). Political economy determinants of agricultural protection levels in EU Member States: an empirical investigation. European Review of Agricultural Economics, 25,463-487. DOI: https://doi.org/10.1093/erae/25.4.463

Organization for Economic Cooperation and Development [OECD] (1987). National policies and agricultural trade. Study on European Economic Community Paris. OECD

OWUTUAMOR, Z.B. and ARENE, C.J. (2018). The impact of foreign direct investment on agricultural growth in Nigeria (1979-2014). Review of Agricultural and Applied Economics. The Successor of the Acta Oeconomica et Informatica, ISSN 1336-9261, XXI 
(Number 1, 2018): 40-54. DOI: UGWU D.S. (2007). Agricultural Extension Practice in 10.15414/raae/2018.21.01.40-54.

Nigeria. Readings in Agricultural Economics and CHIFF, M. and VALDES, A. (1992). A synthesis of the economics in developing countries. Political economy of agricultural pricing policy. Vol. 4. Baltimore: Johns Hopkin University Press.

TYERS, R. and ANDERSON, K. (1992). Disarray in world food markets: A quantitative assessment, New York: Cambridge University Press.

UBOGU, R.E. (1988). Impacts of external economic and trade policies on Nigeria's trade performance, 1960-1986. Economia internationazionale, 41(1-2), 102-122.

Extension (ed.). In CJC Akubuilo, Umebali E.E, Mgbada JU, Ugwu DS, Egwu WE, Awoke MU.

USMAN, F. R., and ARENE, C. J. (2014). Effects of Capital Flight and its Macroeconomic Determinants on Agricultural Growth in Nigeria (1970-2013). International Journal of Food and Agricultural Economics, 2(4), 107-126. ISSN 2147-8988. 